\title{
Purification of Active Peroxidase Isoenzymes and Their Responses to Nitrogen Fertilization and Rotation of Biomass Sorghum"
}

\author{
Jason P. Wight ${ }^{1}$, Frank M. Hons ${ }^{1}$, Sanique M. South ${ }^{2}$, Godson O. Osuji ${ }^{2}$ \\ ${ }^{1}$ Department of Soil and Crop Sciences, Texas A\&M University, College Station, USA; ${ }^{2}$ Biotechnology and Biochemistry Labora- \\ tory, CARC, Prairie View A\&M University, Prairie View, USA. \\ Email: goosuji@pvamu.edu
}

Received August $4^{\text {th }}, 2012$; revised September $1^{\text {st }}, 2012$; accepted September $12^{\text {th }}, 2012$

\begin{abstract}
Peroxidases (EC 1.11.1.7) participate in lignin biosynthesis. But peroxidation is not a tool for assaying lignocellulose metabolism because the active cannot yet be separated from the inactive peroxidases. A biochemical tool for assaying plant cell wall responses to agronomic practices is needed in the lignocellulosic feedstock renewable energy industry. Peroxidase of biomass sorghum was purified to $9-13$ charge isomers by free solution IEF (Rotofor) technique. Free solution IEF was more effective than chromatographic purification of active peroxidase isoenzymes. Native PAGE separated each charge isomer to three anionic and three cationic isoenzymes. Hydrogen peroxide and o-dianisidine assays showed that only $20 \%-30 \%$ of the isoenzymes displayed normal Michaelis-Menten kinetics. Sorghum planted without nitrogen fertilization induced the hydrogen peroxide noncompetitive inhibition of peroxidase, but $280 \mathrm{~kg} \cdot \mathrm{ha}^{-1}$ nitrogen fertilization and $100 \%$ sorghum mineral residue return to the soil tripled the concentration of active peroxidase and relieved the inhibition with concomitant increases of $350 \mathrm{~kg}$ lignin and $3532 \mathrm{~kg} \cdot$ cellulose $\mathrm{ha}^{-1}$. Nitrogen fertilization without crop rotation induced hydrogen peroxide inhibition of the peroxidase, but nitrogen fertilization and $25 \%$ sorghum rotation changed the PI of the active peroxidase from neutral to mildly acidic and relieved the inhibition with concomitant enormous increases of $690 \mathrm{~kg}$ lignin and $7151 \mathrm{~kg} \cdot$ cellulose $\cdot \mathrm{ha}^{-1}$. Hydrogen peroxide inhibition kinetics is consistent with the known peroxidase-substrate intermediate dead-end complex formation. Lignocellulosic yield was greatest under the agronomic management that combined $280 \mathrm{~kg} \cdot \mathrm{ha}^{-1}$ nitrogen fertilizer with $25 \%$ sorghum residue, which resulted in a shift of $\mathrm{pI}$ value of the active peroxidase due to a reduction in the $\mathrm{Km}$ value of the peroxidase. Therefore, up to $75 \%$ of sorghum biomass rather than only $50 \%$ can be harvested for conversion to bioenergy products.
\end{abstract}

Keywords: Oxidoreduction; Isoenzyme Patterns; Inhibition by Hydrogen Peroxide; Lignocellulose Yield; Sorghum-Sorghum Rotation

\section{Introduction}

Peroxidase (EC 1.11.1.7; donor: hydrogen peroxide oxidoreductase) isoenzymes are ubiquitous in plant cells and tissues; and display many isoenzymic forms, up to 15 proteins in alfalfa [1]. They contain heme iron, $\mathrm{Ca}^{2+}$, $\mathrm{Mn}^{2+}, \mathrm{Mg}^{2+}, \mathrm{Cu}^{2+}$ etc prosthetic groups [2,3] and catalyze the oxidation of diverse electron donor substrates (aromatic amines, phenols etc.) using hydrogen peroxide as the terminal electron acceptor [4]. Suggested metabolic roles include oxidation of cinnamyl alcohols during suberin and lignin deposition in the cell wall [5], and formation of cross-links between cell wall proteins, and pectins [6]. Therefore peroxidases are employed in the analytical forensic, biochemical, and paper/pulp Indus-

\footnotetext{
*This research was funded by USDA AFRI (grant \#2011-67009-30050).
}

trial laboratories [7-9]. Although peroxidases participate in cell wall stiffening reactions [10] peroxidation is not a tool for analyzing lignocellulose metabolism because it is not yet possible to separate the active from the inactive peroxidase isoenzymes. Purification of the active isoenzymes would expand and diversify the utility of the enzyme as a biochemical analytical tool especially to optimize and double the production and processing of lignocellulosic feedstocks for the bioenergy industry. Because of the increasing importance of bioenergy to the global energy economics [11], it is necessary to understand the responses of plant cell wall metabolism to the environment. Peroxidases as cell wall-bound enzyme may be of central focus in the envisaged renewable energy studies.

The kinetic properties of crystalline peroxidases have been studied [12], the overall oxidoreductase reactions 
being dominated by the formation of two intermediate complexes (oxidized peroxidase, and partially reduced peroxidase):

$$
\mathrm{E}+\mathrm{H}_{2} \mathrm{O}_{2} \rightarrow \text { Oxidized E }+\mathrm{H}_{2} \mathrm{O}
$$

Oxidized E + Colorless Reductant $\rightarrow$

Partially Reduced E + Colored Reductant

$$
\begin{aligned}
& \text { Partially Reduced E + Colorless Reductant } \rightarrow \\
& \mathrm{E}+\mathrm{H}_{2} \mathrm{O}+\text { Colored Reductant }
\end{aligned}
$$

where $\mathrm{E}$ is the peroxidase, colorless reductant is the electron donor substrate (aromatic amines, phenols etc.), and colored reductant is the one-electron radical product of colorless reductant.

Oxidoreduction by peroxidase is complicated in that oxidized peroxidase and partially reduced peroxidase intermediates are also subject to oxidation by hydrogen peroxide to give inactive (dead-end) forms of peroxidase [12]. This suggests that hydrogen peroxide inhibits peroxidase. The extent of the biochemical inactivation of peroxidase has not been determined. Chromatographic and two-dimensional purification procedures $[1,6,13]$ are inadequate for concentrating the active isoenzymes of peroxidase, removing them from the inactive forms and estimating the extent of the inactivation. Determination of the extent of peroxidase inhibition will further enhance the utility of the enzyme as a marker for analyzing the responses of cell wall metabolism to agronomic management practices that target lignocellulose accumulation for optimization. There are suggestions that the lignocellulose yield of biomass sorghum (Sorghum bicolor L. Moench.) could be increased by returning some of the sorghum and/or mineral residues to the soil $[14,15]$. Return of sorghum residue that contained a lot of lignin resulted in longer soil carbon residence time and overall soil productivity increases [16]. The chemical justification for the effects of sorghum residue return on the lignocellulose yield of the next sorghum crop was not discussed. Since peroxidase is ubiquitous in plant tissues, and is involved in lignin biosynthesis, it is important to investigate the biochemical role of the enzyme if any, in the responses of sorghum cell wall metabolism to residue return management practices. Analytical methods for the concentration and purification of the active isoenzymes of sorghum peroxidase and kinetics determination of their biological role are presented hereunder.

\section{Materials and Methods}

\subsection{Cultivation, Treatments and Harvesting of Sorghum}

The experiment used a randomized complete block design with three treatment factors: crop rotation, nitrogen rate and residue return. Crop rotations were continuous bioenergy sorghum. Sorghum was planted in the spring. Nitrogen was applied to sorghum at 0 or $280 \mathrm{~kg} \cdot \mathrm{N} \cdot \mathrm{ha}^{-1}$. Nitrogen fertilizer as urea was side-dress applied $15-\mathrm{cm}$ deep approximately 6 weeks after planting at the 4-to-5leaf stage for sorghum. Residue return rates were $0 \%$, $25 \%$ or $50 \%$ of sorghum biomass yield at harvest. Each possible combination of residue return, fertilization, and crop rotation was replicated four times. An additional treatment was included with $0 \%$ residue return, but where nutrients removed in aerial sorghum biomass $(\mathrm{P}, \mathrm{K}, \mathrm{Ca}$, $\mathrm{Mg}, \mathrm{Mn}, \mathrm{Zn}, \mathrm{Fe}$, and $\mathrm{Cu}$ ) were returned in mineral form prior to planting the subsequent sorghum crop. These plots also received the non-limiting $\mathrm{N}$ rate [14].

Plots were 9.14-m long, four rows wide and planted on $102-\mathrm{cm}$ row centers, giving a total plot width of $4.08 \mathrm{~m}$. The bioenergy sorghum used in this study was "4-Ever Green", a modern photoperiod-sensitive, one-cross hybrid with high biomass yield and low lodging potentials (Walter Moss Seed Co, Waco, TX, USA). Planting dates ranged from late March to late April, with a rate of 160,000 seeds $\cdot h^{-1}$. Bioenergy sorghum was managed under conventional disk tillage. After the final harvest each year, plots were disked three times to a depth of 15 to $20 \mathrm{~cm}$, and bedded. Furrow irrigation was minimally performed as needed. The plots were harvested using a New Holland model 707U forage chopper (New Holland, PA, USA) and cut to leave a short stubble $(\sim 10 \mathrm{~cm})$ in September of 2011.

For determination of yield, the two inner rows of each plot were weighed using a weight bucket and Avery Weigh-Tronix model RD40RF scale indicator (Illinois Tool Works Inc., Glenview, IL, USA) that were coupled with the harvester. Residue corresponding to $25 \%$ and $50 \%$ of harvested biomass were returned to appropriate plots after each harvest. Water content of aerial plant biomass from each plot was determined by randomly selecting 5 plants, chopping in a commercial chipper/ shredder, and taking an approximately 600 -g subsample. Subsamples were weighed, oven dried at $60^{\circ} \mathrm{C}$ for $7 \mathrm{~d}$, and then re-weighed to determine moisture content.

For peroxidase assay, a sample of sorghum leaf tissue was taken immediately prior to mechanical harvest. Leaf tissue samples were taken by randomly selecting the youngest fully mature leaf from five sorghum plants within each plot. These five entire leaves were removed, placed in a sealed storage container, and immediately brought to $-200^{\circ} \mathrm{C}$ by submersion of the sample container in liquid nitrogen.

\subsection{Fractionation and Assay of Sorghum Peroxidase}

Peroxidase was extracted from sorghum leaves $(50 \mathrm{~g})$ by 
high speed homogenization with $100 \mathrm{~mL}$ of ice-cold 50 $\mathrm{mM} \mathrm{Na} \mathrm{NPO}_{4}$ buffer $\mathrm{pH} 6.0$ containing $25 \%$ polyvinylpyrrolidone $(\mathrm{w} / \mathrm{v})$ and $0.1 \% \beta$-mercaptoethanol [6]. The homogenate was centrifuged at $4000 \mathrm{~g}$ for $30 \mathrm{~min}$ at $4^{\circ} \mathrm{C}$ to pellet cell debris. The supernatant was frozen at $-80^{\circ} \mathrm{C}$, thawed at $5^{\circ} \mathrm{C}$, and centrifuged at $9000 \mathrm{~g}$ for 30 min at $4^{\circ} \mathrm{C}$. The supernatant was made $50 \%$ saturated with solid $\left(\mathrm{NH}_{4}\right)_{2} \mathrm{SO}_{4}$, and the protein precipitated was pelleted by centrifugation at $9000 \mathrm{~g}$ for $30 \mathrm{~min}$ at $4^{\circ} \mathrm{C}$. The pellet was dissolved in minimum volume of extraction buffer, and dialyzed against 3 changes of $10 \mathrm{mM}$ Tris- $\mathrm{HCl}$ buffer $(\mathrm{pH} 8.0)$ at $5^{\circ} \mathrm{C}$, over $48 \mathrm{~h}$, each change being $4 \mathrm{~L}$. Protein precipitate at the end of dialysis was removed by centrifugation $\left(9000 \mathrm{~g} 30 \mathrm{~min} 4^{\circ} \mathrm{C}\right)$.

Partially purified sorghum peroxidase containing $\sim 1 \mathrm{~g}$ protein was made $4 \mathrm{M}$ with deionized urea and $2 \%$ with Bio-Lyte ampholyte (pH $3-10,40 \% \mathrm{w} / \mathrm{v})$. This solution was applied to Rotofor cell (Bio-Rad Laboratories, Hercules CA, USA), and focused for $3.5 \mathrm{~h}$ at $15 \mathrm{~W}$ constant power and at $4{ }^{\circ} \mathrm{C}$. Rotofor fractions were harvested, their $\mathrm{pH}$ values measured. Ampholyte and urea were removed from the fractions by dialyzing at $4^{\circ} \mathrm{C}$ against 3 changes of $10 \mathrm{mM}$ Tris- $\mathrm{HCl}$ buffer ( $\mathrm{pH} 8.0$ ) over $48 \mathrm{~h}$, each change being $4 \mathrm{~L}$. Dialyzed Rotofor fractions were stored in the fridge at $4{ }^{\circ} \mathrm{C}$, and peroxidase remained active for at least 3 weeks.

Dialyzed Rotofor fractions of peroxidase $(0.2 \mathrm{~mL})$ were prepared with bromophenol blue-glycerol protein loading buffer [17] and loaded into the wells of a slab 7.5\% native PAG, and electrophoresed (Bio-Rad protean ii cell, constant $100 \mathrm{~V}$ at $4^{\circ} \mathrm{C}$ ) until the bromophenol blue dye was at the lower edge of the gel. Peroxidase activity was detected by staining [18] the electrophoresed gel in a solution of $50 \mathrm{mM} \mathrm{Na} \mathrm{HPO}_{4}$ containing $6.0 \mathrm{mM}$ o-dianisidine and $8.8 \mathrm{mM}$ hydrogen peroxide at room temperature in the dark until the peroxidase bands became visible (30 - $45 \mathrm{~min}$ ). The stained gel was rinsed with distilled water, photographed, and the peroxidase bands degitalized using UN-SCAN-IT software (Silk Scientific, Utah, USA).

Peroxidase activity was determined at fixed $0.6 \mathrm{mM}$ o-dianisidine concentration, and varied $(0.3-1.8 \mathrm{mM})$ hydrogen peroxide concentrations, in $3 \mathrm{~mL} 50 \mathrm{mM}$ $\mathrm{Na}_{2} \mathrm{HPO}_{4}$ solution $\mathrm{pH}$ 6.0. The activity [18] was measured at $27^{\circ} \mathrm{C}$ using Nanodrop spectrophotometer and calculated at $\mathrm{A}_{460}\left(\epsilon_{460 \mathrm{~nm}}: 11.3 \mathrm{mM}^{-1} \cdot \mathrm{cm}^{-1}\right)$ for double reciprocal plots. Protein concentrations were determined by the Folin-Ciocalteau reagent and lysozyme as protein standard.

\subsection{Determination of Cellulose and Lignin Yields}

Dry, composited and milled sorghum shoots (200 g) harvested per field plot treatment were custom (Universal
Testing, Illinois, USA) analyzed for lignin, acid and neutral detergent fiber (ADF and NDF) by standard gravimetric method.

\section{Results and Discussion}

\subsection{Separation of Active from Inactive Isoenzymes of Peroxidase}

The active isoenzymes of sorghum peroxidase were separated from the inactive ones by free solution (Rotofor) isoelectric focusing (IEF) technology that has been very successful in fractionating the complex 28 isoenzymes of glutamate dehydrogenase [19]. Rotofor IEF separated the isoenzyme population into 9 - 13 charge isomers similar to other peroxidases [1]. They were arranged in three groups: negatively charged, neutral, and mildly alkaline isoenzymes (Figure 1). This was the important step in the separation of the active from the inactive peroxidase isoenzymes, most of which were acidic $(\mathrm{pI}<4.8)$ charge isomers. Chromatographic and two-dimensional purification procedures had been inadequate for concentrating the active isoenzymes of peroxidase, and removing them from the inactive forms $[1,2,13]$. Native polyacrylamide gel electrophoresis (PAGE) of the charge isomers revealed the two distinct groups (anionic and cationic) of peroxidase isoenzymes that make up the charge isomers (Figure 1). The highly acidic ( $\mathrm{pI}<4.5$ ) charge isomers contain predominantly the anionic isoenzymes; the weakly basic ( $\mathrm{pI}>7.5$ ) contain predominantly the cationic isoenzymes; whilst the neutral charge isomers consist of graded mix of anionic and cationic isoenzymes. There were three rows of peroxidase isoenzymes, three in the cationic group and three in the anionic group; and they varied in relative concentration and distribution patterns/ profile according to the prevalent crop rotation and nitrogen fertilization (Figure 1).

\subsection{Responses of Peroxidase to Sorghum Rotation and Nitrogen Fertilization}

The active peroxidase isoenzyme distribution patterns responded in different ways to the various agronomic management practices (Figure 1). Digital quantitation of the isoenzyme bands showed that nitrogen fertilization of the sorghum did not alter the pI values of the active isoenzymes but tripled their yield (Figures 1(a) and (b)). Under identical nitrogen fertilization, $25 \%$ crop rotation (addition of $25 \%$ sorghum residue to the soil) shifted the pI values of the active isoenzyme from neutral to slightly acidic (Figures 1(c) and (d)). Under identical level of sorghum residue in the soil, nitrogen fertilization doubled the concentration of the active cationic isoenzymes (Figures 1(e) and (f)). These differences permitted the kinetics characterization of the responses of peroxidase to 
Rotofor IEF Chambers

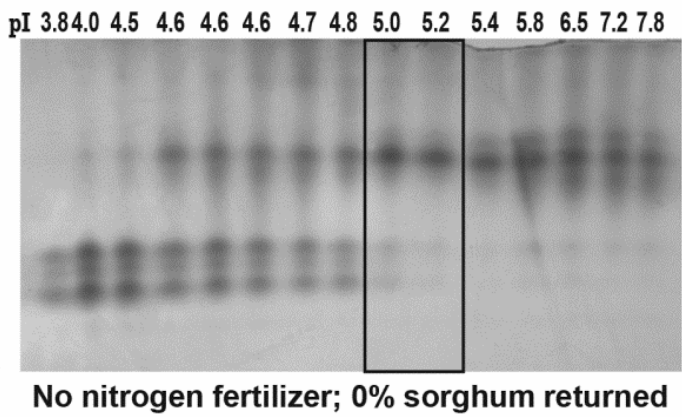

(a)

\section{Rotofor IEF Chambers}

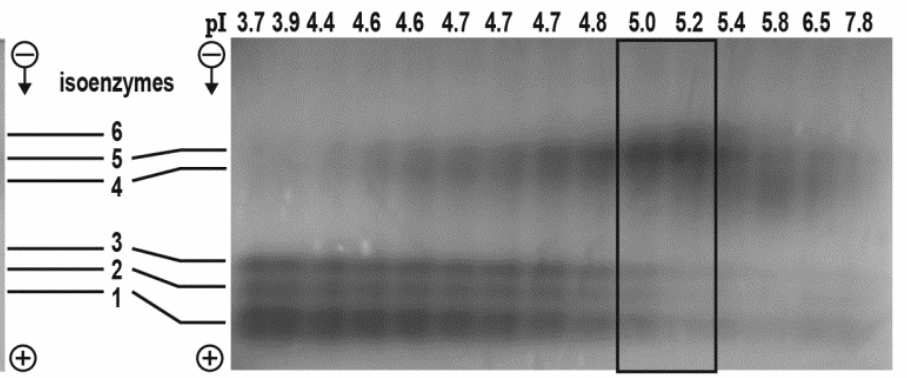

$280 \mathrm{~kg}$ nitrogen fertilizer; $100 \%$ mineral returned

(b)

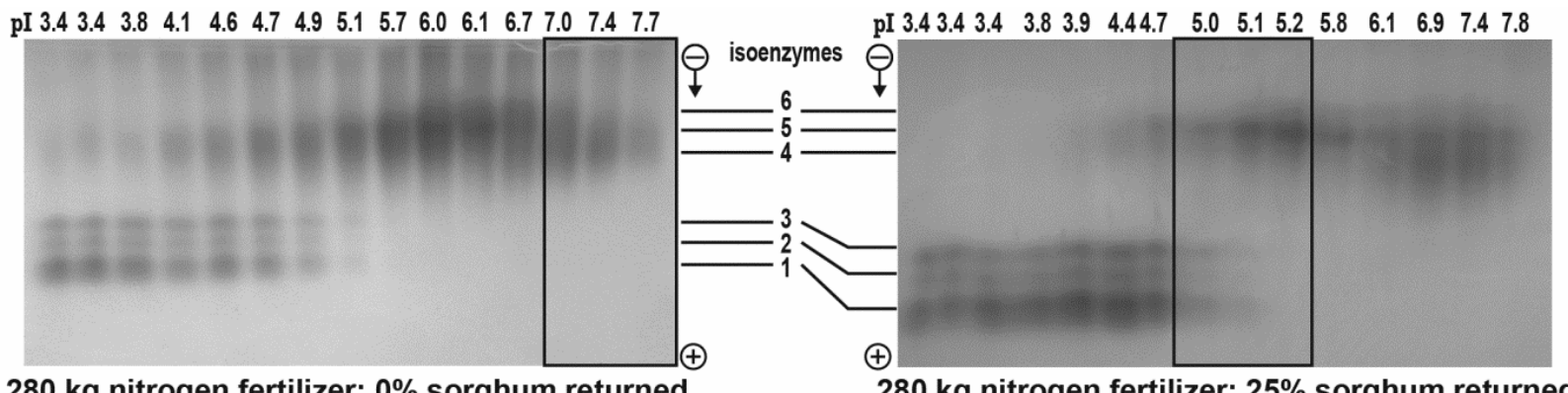

$280 \mathrm{~kg}$ nitrogen fertilizer; $0 \%$ sorghum returned

(c)

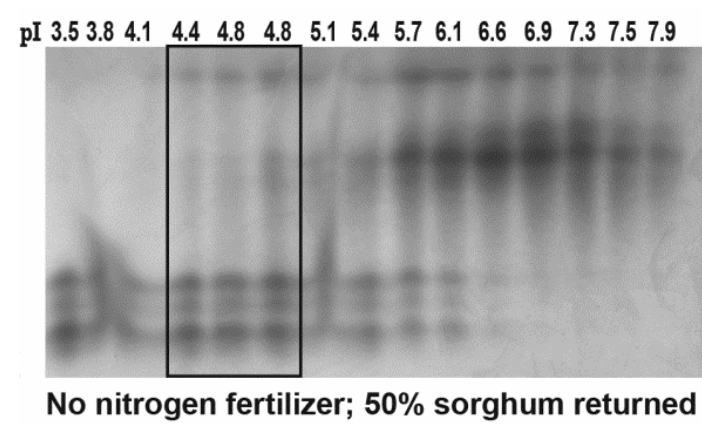

(e)

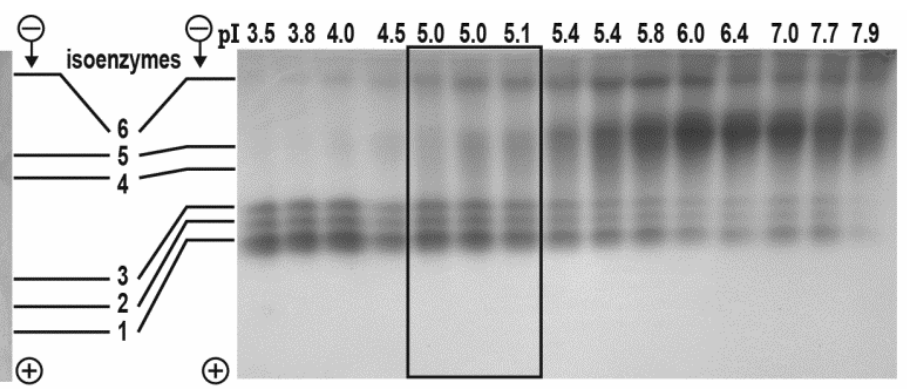

$280 \mathrm{~kg}$ nitrogen fertilizer; $\mathbf{5 0 \%}$ sorghum returned

(f)

Figure 1. Distribution patterns of active and inactive biomass sorghum peroxidase isoenzymes after free solution IEF followed by native polyacrylamide gel electrophoresis. The active charge isomers of peroxidase are boxed; the inactive ones are not boxed.

agronomic management of sorghum.

\subsection{Peroxidase Kinetics}

The active peroxidase isoenzymes that displayed normal Michaelis-Menten kinetics (Figure 2) at constant odianisidine (substrate) and variable hydrogen peroxide concentrations [6] were only $20 \%-30 \%$ of the total isoenzymes (Figure 1); the majority was inactive displaying aberrant Michaelis-Menten kinetics. In all the sorghum samples, almost all the strongly acidic charge isomers were inactive, thus suggesting that the acidic isoenzymes were the degradation products of the inactivated isoenzymes. In the mechanism of peroxidase reac- tion, when the oxidized peroxidase (Equation (1)), and partially reduced peroxidase (Equation (2)) become oxidized by hydrogen peroxide, dead-end enzyme-substrate complexes are formed [8]. Inactive forms of enzymes are targeted for degradation, producing progressively lower molecular weight polypeptides [20,21].

Double reciprocal plots of the active charge isomers gave distinct pairs of treated sorghums, one member of the pair being the noncompetitively inhibited [22] peroxidase. The peroxidase of sorghum treated with 280 $\mathrm{kg} \cdot \mathrm{ha}^{-1}$ of nitrogen fertilizer and $100 \%$ sorghum mineral residue in the soil had a Vmax value of 53.1 mmoles $\cdot \min ^{-1} \cdot \mathrm{mg}^{-1}$ protein, but the Vmax value decreased 


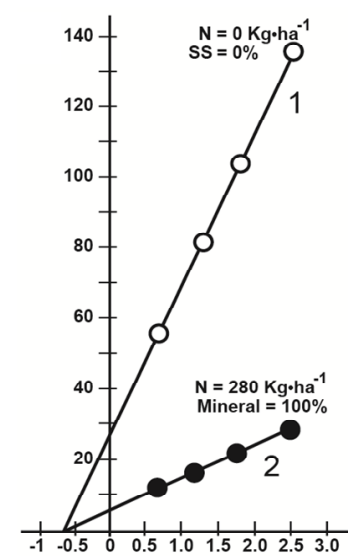

(a)

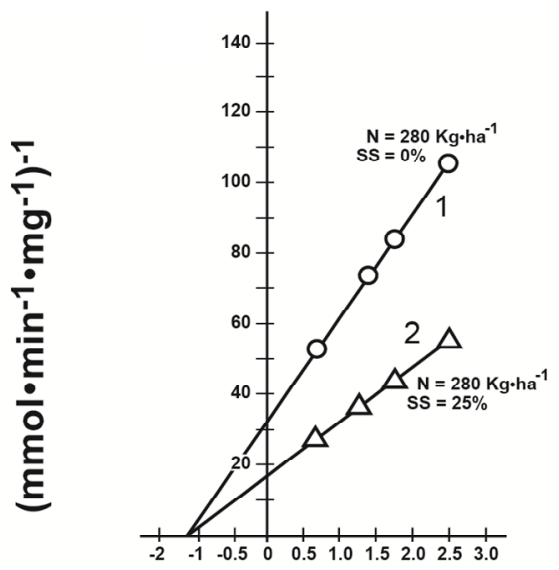

(b)

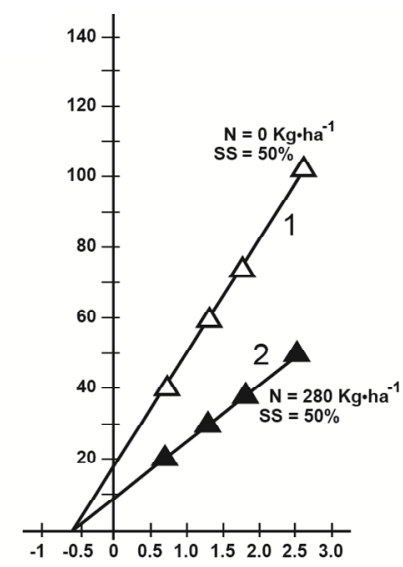

\section{Hydrogen Peroxide (mM)-1}

(c)

Figure 2. Noncompetitive inhibition kinetics of sorghum peroxidase. O-dianisidine saturation of peroxidase activities at varied concentrations of hydrogen peroxide $(0.4,0.57,0.85$, and $1.7 \mathrm{mM}$ ) were performed. Under each pair of treated sorghum, graphs \#1 and \#2 were the inhibited and not inhibited sorghum peroxidases respectively. Calculated Vmax and $\mathrm{Km}$ values are listed in Table 1 . SS is Sorghum-Sorghum rotation. to $4.8 \mathrm{mmoles} \cdot \mathrm{min}^{-1} \cdot \mathrm{mg}^{-1}$ protein in the control sorghum without nitrogen fertilizer and no sorghum residue returned to the soil (Figure 2(a)). Therefore control sorghum without urea fertilization and without crop rotation (sorghum residue in the soil) induced hydrogen peroxide noncompetitive inhibition of the peroxidase.

The peroxidase of sorghum treated with $280 \mathrm{~kg} \cdot \mathrm{ha}^{-1}$ nitrogen fertilizer together with $25 \%$ sorghum residue return to the soil had a Vmax value of 10.2 mmoles $\cdot \mathrm{min}^{-1} \cdot \mathrm{mg}^{-1}$ protein, but the Vmax value decreased to $3.3 \mathrm{mmoles} \cdot \mathrm{min}^{-1} \cdot \mathrm{mg}^{-1}$ protein in the control sorghum with $280 \mathrm{~kg} \cdot \mathrm{ha}^{-1}$ nitrogen fertilizer without sorghum residue in the soil (Figure 2(b)). Therefore, control sorghum without sorghum residue even in the presence of nitrogen fertilization induced hydrogen peroxide noncompetitive inhibition of peroxidase.

The peroxidase of sorghum treated with $280 \mathrm{~kg} \cdot \mathrm{ha}^{-1}$ of nitrogen fertilizer together with $50 \%$ sorghum rotation had a Vmax value of $6.6 \mathrm{mM} \cdot \mathrm{min}^{-1} \cdot \mathrm{mg}^{-1}$ protein, but the Vmax value decreased to $3.8 \mathrm{mM} \cdot \mathrm{min}^{-1} \cdot \mathrm{mg}^{-1}$ protein in the control sorghum without nitrogen fertilizer but with $50 \%$ sorghum rotation (Figure 2(c)). Therefore, control sorghum without nitrogen fertilization even in the presence of $50 \%$ sorghum residue in the soil induced the hydrogen peroxide noncompetitive inhibition of peroxidase.

Absence of sorghum rotation or mineral residue and/or nitrogen fertilizer decreased the peroxidase activity whilst presence of sorghum rotation or sorghum mineral residue and nitrogen fertilizer increased the peroxidase activity. The $50 \%$ sorghum residue in the soil was in excess of the requirement for normal peroxidase activity. These results offer the biochemical explanation for earlier agronomic observations [14] that sorghum-corn rotation improved sorghum yield and mineral nutrient cycling of the soil. Agricultural practices involving crop rotation and nitrogen fertilization are biochemically more favorable for sorghum peroxidase activity than absence of crop rotation and nitrogen fertilization. The noncompetitive inhibition kinetics (Figure 2) under variable hydrogen peroxide concentrations is consistent with the known mechanisms of peroxidase involving oxidized peroxidase and partially reduced peroxidase as enzyme-substrate intermediate complexes that form dead-end products with hydrogen peroxide [12].

\subsection{Lignin and Cellulose Yields}

When nitrogen fertilization of the sorghum tripled the yield of active peroxidase isoenzymes (Figure 1(b)) and relieved the inhibition on the peroxidase of the untreated control sorghum (Figure 2(a)), the lignin and cellulose contents increased by $350 \mathrm{~kg}$ and $3532 \mathrm{~kg} \cdot \mathrm{ha}^{-1}$ respectively (Table 1). Under identical nitrogen fertilization, when the addition of $25 \%$ sorghum residue to the soil 
Table 1. Responses of sorghum peroxidase kinetic properties and lignocellulose contents to nitrogen fertilization and sorghum rotation.

\begin{tabular}{|c|c|c|c|c|}
\hline Management Practice & Lignin* & NDF $^{\$}$ & Vmax ${ }^{z}$ & $\mathbf{K m}^{\omega}$ \\
\hline $0 \mathrm{~kg} \cdot \mathrm{ha}^{-1}$ nitrogen; $0 \%$ sorghum residue & 648.1 & 7258.7 & 4.8 & 0.78 \\
\hline $280 \mathrm{~kg} \cdot \mathrm{ha}^{-1} \mathrm{~N} ; 100 \%$ sorghum residue & 998.0 & 10791.0 & 53.1 & 0.78 \\
\hline $280 \mathrm{~kg} \cdot \mathrm{ha}^{-1} \mathrm{~N} ; 0 \%$ sorghum residue & 556.6 & 6632.1 & 3.3 & 0.39 \\
\hline $280 \mathrm{~kg} \cdot \mathrm{ha}^{-1} \mathrm{~N} ; 25 \%$ sorghum residue & 1246.2 & 13783.0 & 10.2 & 0.39 \\
\hline $0 \mathrm{~kg} \cdot \mathrm{ha}^{-1} \mathrm{~N} ; 50 \%$ sorghum return & 480.0 & 6176.0 & 3.8 & 0.78 \\
\hline $280 \mathrm{~kg} \cdot \mathrm{ha}^{-1} \mathrm{~N} ; 50 \%$ sorghum return & 867.7 & 10337.5 & 6.6 & 0.78 \\
\hline
\end{tabular}

Notes: Lignin ${ }^{*}$ and $\mathbf{N D F}^{\$}$ are $\mathrm{kg}$ per hectare; $\mathbf{V} \mathbf{m a x}^{\mathbf{z}}$ are $\mathrm{mM} \cdot \mathrm{min}^{-1} \cdot \mathrm{mg}^{-1}$ protein; $\mathbf{K m}^{\omega}$ are $\mathrm{mM} \mathrm{H}_{2} \mathrm{O}_{2}$

shifted the $\mathrm{pI}$ values of the active isoenzyme from neutral to slightly acidic (Figure 1(d)), and relieved the inhibition on the peroxidase of the control sorghum (Figure 2(b)), the lignin and cellulose contents increased enormously by $690 \mathrm{~kg}$ and $7151 \mathrm{~kg} \cdot \mathrm{ha}^{-1}$ respectively (Table 1). Under identical sorghum rotation $(50 \%)$, addition of 280 $\mathrm{kg} \cdot \mathrm{ha}^{-1}$ nitrogen fertilizer doubled the concentration of the cationic isoenzymes (Figure 1(f)), and relieved the inhibition on the peroxidase that was observed in the control sorghum (Figure 2(c)) thereby increasing the lignin and cellulose contents by $388 \mathrm{~kg}$ and $4162 \mathrm{~kg} \cdot \mathrm{ha}^{-1}$ respectively (Table 1) in the fertilized sorghum. In all the pairwise kinetics of sorghum peroxidase (Figure 2), the nitrogen fertilization in conjunction with sorghum rotation improved the kinetics properties of the peroxidase isoenzymes with concomitant increases in the yields of lignocellulose. Therefore, the peroxidase kinetics agree with their biological role as cell wall-bound enzymes that stiffen cell walls by participating in the biosynthesis of lignin, suberin etc. [4-6].

The best lignocellulosic yield was produced by the agronomic management that combined $280 \mathrm{~kg} \cdot \mathrm{ha}^{-1} \mathrm{ni}-$ trogen fertilizer with $25 \%$ sorghum residue and shifted the pI value of the active peroxidase because the $\mathrm{Km}$ value of the peroxidase decreased concomitantly to 0.39 $\mathrm{mM}$ from the higher $\mathrm{Km}$ values $(0.78 \mathrm{mM})$ of the other sorghums (Table 1). These Km values for hydrogen peroxide are much lower than earlier results [13] probably because the inactive isoenzymes of the sorghum peroxidase had been removed (Figure 1). This is further support to the increases in the Vmax values. The lowering of the $\mathrm{Km}$ values for hydrogen peroxide increased the affinity of peroxidases and their capacity to synthesize lignin and suberin for the stiffening of mechanical tissues etc. $[5,6,10]$. Therefore, there were agreements between peroxidase isoenzyme patterns, their activation, kinetics, and the yields of lignocellulose in the responses of sorghum to crop rotation and nitrogen fertilization. The agreements were made possible because the inactive peroxi- dase had been removed from the active isoenzymes, thus could constitute an analytical biochemistry framework for expanding the utility of peroxidase kinetics to evaluate lignocellulose production in the bioenergy industries [7-9], and generally for monitoring the effects of agronomic practices on crop metabolism.

Return of $25 \%$ of the sorghum residue to the soil induced the next sorghum crop to produce almost double yields of lignin and cellulose compared with when 50\% of sorghum residue was returned to the soil (Table 1). Therefore, up to $75 \%$ of sorghum biomass rather than only $50 \%$ can be harvested for conversion to bioenergy products. High yield of biomass feedstock per unit area of land is a prerequisite for successful bioenergy industry [23]. Removal of $100 \%$ of the sorghum biomass without any returned to the soil produced peroxidase isoenzymes of very low activities (Figures 1(a) and (c)) in the next crop of sorghum exhibiting lowered yields of lignin and cellulose (Table 1). Results discussed in Figures 1 and 2 and Table 1 begin to provide some biochemical explanation for previous observations $[14,15]$ that return of sorghum residues to the soil improved soil organic carbon contents, nutrient cycling, and the biomass yield of the next crop of sorghum. Changes in the charge of the isoenzymes (Figure 1) in response to the returned sorghum residue may be related to the prosthetic $\mathrm{Ca}^{2+}, \mathrm{Mg}^{2+}, \mathrm{Mn}^{2+}$, heme iron etc components of the peroxidase kinetic pathways [1-3,12]. Lignin is a major component of crop residue, and it is slow to degrade in the soil [16] thereby ensuring high soil carbon contents in the long-term for efficient macro and micro-nutrient exchange. In this regard, return of high-lignin sorghum residue $\left(1246 \mathrm{~kg} \cdot \mathrm{ha}^{-1}\right)$ to the soil should be more beneficial than low-lignin sorghum residue $\left(557 \mathrm{~kg} \cdot \mathrm{ha}^{-1}\right)$.

\section{Conclusion}

Free solution IEF is more effective than chromatographic purification of active peroxidase isoenzymes. Rotofor IEF successfully separated the isoenzyme population into charged isomers similar to other peroxidases. These populations were arranged into three groups: negatively charged, neutral, and mildly alkaline isoenzymes. Active peroxidase isoenzyme distribution patterns responded in the various agronomic management practices. Digital quantitation of isoenzyme bands showed that nitrogen fertilization of the sorghum and $100 \%$ mineral residue return did not alter the $\mathrm{pI}$ values of the active isoenzymes but tripled their yield. Nitrogen fertilization of the sorghum tripled the yield of active peroxidase isoenzymes and relieved the inhibition on the peroxidase of the untreated control sorghum. This resulted in lignin and cellulose contents that were increased by $350 \mathrm{~kg}$ and $3532 \mathrm{~kg} \cdot \mathrm{ha}^{-1}$ respectively. Agricultural systems in which $100 \%$ of the 
sorghum biomass was removed produced peroxidase isoenzymes of very low activities in the next crop of sorghum, exhibiting lowered yields of both lignin and cellulose. Changes in the charge of the isoenzymes in response to the returned sorghum residue may be related to the prosthetic $\mathrm{Ca}^{2+}, \mathrm{Mg}^{2+}, \mathrm{Mn}^{2+}$, heme iron etc components of the peroxidase kinetic pathways. The best lignocellulosic yield was produced by the agronomic management that combined $280 \mathrm{~kg} \cdot \mathrm{ha}^{-1}$ nitrogen fertilizer with $25 \%$ sorghum residue and shifted the pI value of the active peroxidase because the $\mathrm{Km}$ value of the peroxidase decreased concomitantly. Therefore, up to $75 \%$ of sorghum biomass rather than only $50 \%$ can be harvested for conversion to bioenergy products.

\section{REFERENCES}

[1] G. Gramss and O. Rudeschko, "Activities of Oxidoreductase Enzymes in Tissue Extracts and Sterile Root Exudates of Three Crop Plants and Some Properties of Peroxidase Component," New Phytologist, Vol. 138, No. 3, 1998, pp. 401-409. doi:10.1046/j.1469-8137.1998.00128.x

[2] O. Omidiji, J. Okpuzor and O. Otubu, "Peroxidase Activity of Germinating Sorghum Bicolor Grains: Effect of Some Cations," Journal of Science Food Agriculture, Vol. 82, No. 15, 2002, pp. 1881-1885. doi:10.1002/jsfa.1144

[3] W. He, H. Jia, Li. Yan, J. Li, H. Zhao, L. Mi and Z. Zheng, "Understanding the Formation of CuS Conclave Superstructures with Peroxidase-Like Activity," Nanoscale, Vol. 4, 2012, pp. 3501-3506.

[4] H. B. Dunford, "Horseradish Peroxidase: Structure and Kinetic Properties," In: K. E. Everse and M. B. Grisham, Eds., Peroxidase in Chemistry and Biology, CRC Press, Boca Raton, 1991, pp. 1-24.

[5] R. W. Whitten, J. J. MacKay and R. R. Sederoff, "Recent Advances in Understanding Lignin Biosynthesis," Annual Reviews Plant Physiology and Plant Molecular Biology, Vol. 49, 1998, pp. 585-609. doi:10.1146/annurev.arplant.49.1.585

[6] M. Quiroga, C. Guerrero, M. A. Botella, A. B. Iraida, M. I. Medina, F. J. Alonso, S. M. de Forchetti, S. M. Tigier and V. Valpuesta, "A Tomato Peroxidase Involved in the Synthesis of Lignin and Suberin," Plant Physiology, Vol. 122, No. 4, 2000, pp. 1119-1127. doi:10.1104/pp.122.4.1119

[7] L. Gorton, "Carbon Paste Electrodes Modified with Enzymes, Tissues, and Cells," Electroanalysis, Vol. 7, No. 1, 1995, pp. 23-45. doi:10.1002/elan.1140070104

[8] I. Y. Sakharov, M. K. Vesga, B. Galaev, I. V. Sakharova and O. Y. Pletjushkina, "Peroxidase from Leaves of Palm Tree," Plant Science, Vol. 161, No. 5, 2001, pp. 853-860. doi:10.1016/S0168-9452(01)00466-6

[9] H. E. Schoemaker, W. H. J. Boesten, W. J. J. van den Tweel, Q. B. Broxterman and J. Kamphuis, "Biocatalysis in Organic Synthesis," Proceedings of the 6th European Congress on Biotechnology, Florence, 13-17 June 1993, pp. 17-26.

[10] J. Andrews, M. Malone, D. S. Thompson, L. C. Ho and K. S. Burton, "Peroxidase Isoenzyme Patterns in the Skin of Maturing Tomato Fruit," Plant, Cell and Environment, Vol. 23, No. 4, 2000, pp. 415-422. doi:10.1046/j.1365-3040.2000.00555.x

[11] L. Wright, "Worldwide Commercial Development of Bioenergy with Focus on Energy Crop-Based Projects," Biomass and Bioenergy, Vol. 30, No. 8-9, 2006, pp. 706-714. doi:10.1016/j.biombioe.2005.08.008

[12] D. J. Schuller, N. Ban, R. B. van Huystee, A. McPherson and T. L. Poulos, "The Crystal Structure of Peanut Peroxidase," Current Biology, Vol. 4, 1996, pp. 311-321.

[13] H. P. R. Maciel, C. M. C. P. Gouvea, M. Toyama, M. Somlka, S. Marangoni and G. M. Pastore, "Extraction, Purification and Biochemical Characterization of a Peroxidase from Copaifera Langdorffi Leaves," Química Nova, Vol. 30, 2007, pp. 1067-1071. doi:10.1590/S0100-40422007000500003

[14] J. P. Wight, F. M. Hons, J. O. Storlien, T. L. Provin, H. Shahandeh and R. P. Wiedenfeld, "Management Effects on Bioenergy Sorghum Growth, Yield, and Nutrient Uptake," Biomass and Bioenergy, 2012, in press. doi:10.1016/j.biombioe.2012.06.036

[15] J. M. Powell and F. M. Hons, "Sorghum Stover Removal Effects on Soil Organic-Matter Content, Extractible Nutrients and Crop Yield," Journal of Sustainable Agriculture, Vol. 2, No. 1, 1991, pp. 25-39. doi:10.1300/J064v02n01_04

[16] A. L. Wright, F. Dou and F. M. Hons, "Crop Species and Tillage Effects on Carbon Sequesteration in Subsurface Soil," Soil Science, Vol. 172, No. 2, 2007, pp. 124-131. doi:10.1097/SS.0b013e31802d11eb

[17] L. G. Davis, M. D. Dibner and J. F. Battey, "Basic Methods in Molecular Biology,” Elsevier, New York, 1986.

[18] M. A. Quesada, H. A Tigier, M. J. Bukovac and V. Valpuesta, "Purification of an Anionic Isoperoxidase from Peach Seeds and Its Immunological Comparison with Other Anionic Isoperoxidases," Plant Physiology, Vol. 79, No. 4, 1990, pp. 623-628. doi:10.1111/j.1399-3054.1990.tb00035.x

[19] G. O. Osuji, T. K. Brown, S. M. South, J. C. Duncan and D. Johnson, "Doubling of Crop Yield through Permutation of Metabolic Pathways," Advances Bioscience and Biotechnology, Vol. 2, 2011, pp. 364-379. doi:10.4236/abb.2011.25054

[20] M. Desimone, A. Henke and E. Wagner, "Oxidative Stress Induces Partial Degradation of the Large Subunit of Ribulose-1,5-bisphosphate Carboxylase/Oxygenase in Isolated Chloroplasts of Barley," Plant Physiology, Vol. 111, 1996, pp. 789-796.

[21] G. O. Osuji, C. Braithwaite, R. Pointer and J. Reyes, "Pesticide Inactivation of Peanut Glutamate Dehydrogenase: Biochemical Basis of the Enzyme's Isomerization," Journal of Agricultural and Food Chemistry, Vol. 47, No. 8, 1999, pp. 3345-3351. doi:10.1021/jf980531v

[22] I. H. Segel, "Biochemical Calculations," 2nd Edition, J. 
Wiley \& Sons, New York, 1976.

[23] R. D. Perlack, L. L. Wright, A. F. Turhollow, R. L. Graham, B. J. Stokes and D. C. Erbach, "Biomass and Feedstock for a Bioenergy and Bioproducts Industry: Techni- cal Feasibility of a Billion-Ton Annual Study," ORNL/ TM-2006/66, Oak ridge National Laboratory, Oak ridge, 2005. 